\title{
RETHINKING PATENT LAW'S PRESUMPTION OF VALIDITY ${ }^{1}$
}

\author{
Doug Lichtman² \& Mark A. Lemley ${ }^{3}$
}

1. (C) 2007 Mark A. Lemley \& Doug Lichtman. DRAFT 7/30/07. Comments welcome at either lichtman@law.ucla.edu or MLemley@law.stanford.edu. We expect a final version of the paper to be available by 10/1/07 (email us if you would like a copy) and published soon thereafter in the Stanford Law Review.

2. Professor of Law, UCLA.

3. William H. Neukom Professor, Stanford Law School; of counsel, Keker \& Van Nest LLP. Sincere thanks to the many readers who offered comments on earlier drafts, including Bob Armitage, Jason Bordoff, Chris Cotropia, Dennis Crouch, Michael Deich, John Duffy, Rob Gordon, Rose Hagan, Scott Hemphill, Tim Holbrook, Stephen Merrill, Adam Mossoff, Peter Orszag, Andrew Pincus, Eric Posner, Meeghan Prunty, Arti Rai, Tim Taylor, Sam Vermont, and participants in workshops at George Mason and Microsoft Corp.. This piece develops an idea that we first wrote about for a non-legal audience nearly two years ago in a piece coauthored with Bhaven Sampat. See Mark A. Lemley, Douglas Lichtman \& Bhaven N. Sampat, What to Do About Bad Patents, Regulation Magazine, Winter 2005-2006, at 10. This follow-on work was funded in part by the Hamilton Foundation. 


\begin{abstract}
The United States Patent and Trademark Office is tasked with the job of reading patent applications and determining which ones qualify for patent protection. It is a Herculean task, and the Patent Office pursues it subject to enormous informational and budgetary constraints. Nonetheless, under current law, courts are bound to defer to the Patent Office's decisions regarding patent validity. In this Article, we argue for reform. Deference to previous decision-makers is appropriate in instances where those previous decisions have a high likelihood of accuracy, and the patent system should endeavor to create processes that fit this mold. But granting significant deference to the initial process of patent review is indefensible and counter-productive. Patents should be vulnerable to challenge until and unless they are significantly evaluated in an information-rich environment. At that point, they will have earned and therefore should be accorded a presumption of validity. Such an approach would better serve the patent's systems long-run incentive goals, and it would give patent applicants better incentives to file for genuine inventions but leave their more obvious and incremental accomplishments outside the patent system's purview. Here, we therefore suggest the creation of a two-tier system of patent validity, with patents that are subject to intensive scrutiny accorded a strong presumption of validity, while untested patents are left to be evaluated more fully in court.
\end{abstract}




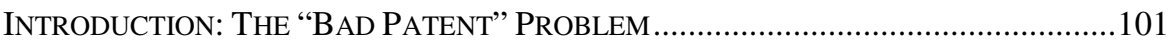

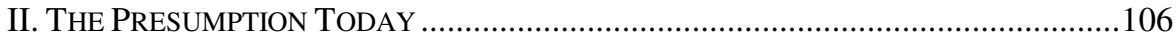

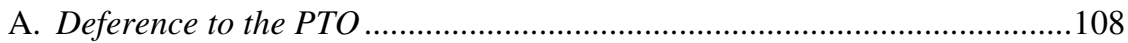

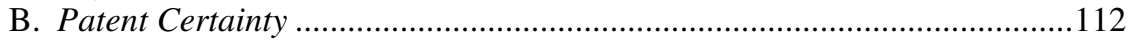

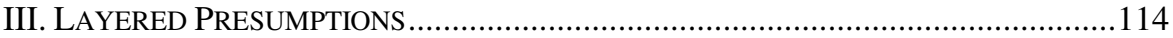

A. Eliminate the Clear and Convincing Evidence Presumption ....................115

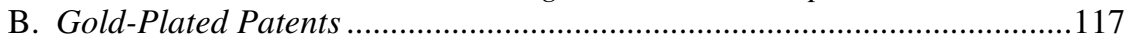

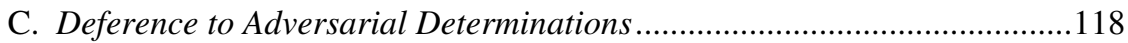

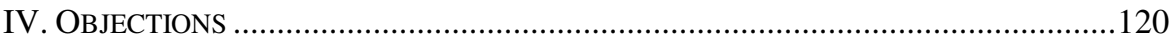

A. Layered Presumptions Favor Patent Applicants Who Have Adequate Resources Over Individual Inventors and Start-ups...............................120

B. Reducing the Presumption of Validity Will Encourage Frivolous Validity Challenges and Wasteful Searches for Obscure Prior Art. ...........121

C. Trained Patent Examiners Are Better at Determining Validity than Generalist Judges and Lay Juries. ..................................................... 123

D. The PTO Will Have Incentives to Grant Bad Gold-Plated Patents............123

E. Presumptions Don't Matter Anyway........................................................123

V. EFFECTS ON CURRENT STAKEHOLDERS .................................................... 125

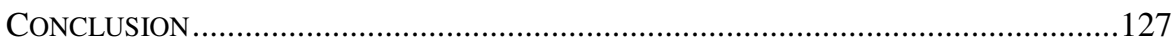

\section{INTRODUCTION: THE “BAD PATENT” PROBLEM}

The United States Patent and Trademark Office (PTO) is tasked with the job of reading patent applications and determining which ones qualify for patent protection. It is a Herculean task. One problem is resources. The PTO expects more than 400,000 new patent applications to be filed in $2007 .{ }^{4}$ To accurately evaluate the merits of all of those purported inventions would cost billions. Add to that the administrative costs of both interacting with all of the relevant lawyers and documenting the entire process, and the required budget would make patent application fees prohibitively expensive. ${ }^{5}$

Information is a second significant impediment to PTO review. Patent applications are evaluated early in the life of a claimed technology, and thus at the time of patent review there is typically no publicly available information about matters such as how well the technology has been received by experts in the field, or whether consumers have deemed the technology to represent in some way an advance over existing alternatives. Worse, patent examiners

4. U.S. Patent \& Trademark Office, 2007-2012 Strategic Plan, available at http://www.uspto.gov/web/offices/com/strat2007.

5. See Mark A. Lemley, Rational Ignorance at the Patent Office, 95 Nw. U. L. REV. 1495 (2001) (making this point) [hereinafter, Lemley, Rational Ignorance]. 
cannot solicit these sorts of credible outsider opinions, not only because for many technologies it is unclear at the early stages who the relevant experts and customers might be, but also because patent evaluation is at least in part a confidential conversation between applicant and examiner, ${ }^{6}$ designed to keep an applicant's work secret just in case the patent application is ultimately denied. $^{7}$

Given all this, it is hardly a surprise that the PTO makes mistakes during the initial process of patent review, granting patents that, on the merits, should never have been issued. ${ }^{8}$ The real surprise is that the law makes issuance mistakes hard to reverse.

The culprit is a legal doctrine known as the presumption of validity. Under that doctrine, courts are obligated to defer to the PTO's initial determination that an invention qualifies for patent protection unless the defendant can show by "clear and convincing" evidence that the PTO erred. Thus, if the PTO issues a patent covering a technology that the purported inventor did not in fact pioneer, defendants face an uphill battle persuading the courts to overrule that errant determination. The theoretical justification is that patent examiners have expertise when it comes to questions of patent validity, and thus, if patent

6. Until 1999, patent applications were kept secret in the United States. Most—but not all-applications are now published eighteen months after they are filed. 35 U.S.C. $\S 122(\mathrm{~b})$. But they are kept confidential until then.

7. For an interesting proposal to change this by instituting outside peer review of patents, see Beth Simone Noveck, "Peer to Patent": Collective Intelligence, Open Review, and Patent Reform, _ Harv. J.L. \& Tech. _ (2006). The PTO is experimenting with such a procedure as a pilot project, but because of the confidentiality restriction they are doing so only for patent applicants who voluntarily agree to such review. This sort of "open source" review of patent applications when they are filed faces a number of hurdles. Among the many issues: adversaries often do not know they are adversaries that early in the life of a patent, and thus the right firms and individuals will typically not show up to this new PTO process; moreover, the individuals with the best information and insight likely have neither the time nor the inclination to participate in the sort of volunteer project, given that there are no rewards for doing so and there is a real risk that participation will ultimately lead to increased liability if the patent issues and a participating evaluator nevertheless infringes. This doesn't mean that the program can't help identify prior art for patents that people care enough to evaluate, but it does mean that it is unlikely to replace rather than merely supplement some more general form of review.

8. Calls for patent reform have echoed loudly over the past several years, with industry organizations, patent scholars, and government agencies all publicly announcing that the patent system is broken and that the PTO in particular is letting a large number of undeserving patents be issued. See, e.g., Federal Trade Commission, To Promote Innovation: The Proper Balance of Competition and PATent LaW And Policy (2003), available at www.ftc.gov/os/2003/10/innovationrpt.pdf; ADAM B. JAFFE \& JOSHUA LERNER, InNOvation AND ITS Discontents (2004); A PATENT System for the 21st Century (Stephen A. Merrill, Richard C. Levin, and Mark B. Myers, eds., 2004). Even the mass media has picked up on the theme, frequently poking fun at PTO mistakes that are so obvious that a lay audience can appreciate the errors. See Editorial, Patently Ridiculous, N.Y. Times, Mar. 22, 2006, at A24; Editorial, U.S. Patent System Has Run Aground, Boston Herald, July 24, 2005, at 26; Sara Schaefer Munoz, Patent No. 6,004,596: Peanut Butter and Jelly Sandwich, WALl ST. J., Apr. 5, 2005, at B1. 
examiners have decided that a given invention qualifies for protection, judges and juries should not second-guess the experts. ${ }^{9}$ But the reality is that PTO expertise is brought to bear under such poor conditions that any advantages associated with expertise are overwhelmed by the disadvantages associated with insufficient funding and inadequate outsider information. Contrast that to court review, where information is a natural product of the adversarial process, and where financial constraints are reduced because only a tiny fraction of all issued patents end up sufficiently valuable and contentious to warrant litigation.

Thus, the presumption of validity backfires. Rather than protecting accurate initial decisions from inefficient later meddling, the presumption precludes what would often be a worthwhile second look. As a result, courts today regularly enforce overbroad and undeserved patents, and strategic applicants continue to apply for undeserved patents knowing that there is a good chance the PTO will err.

This is a substantial, real-world problem. Under normal circumstances, a patent holder earns a living first by patenting a genuine invention, and then by telling potential customers about the technology. The patent in this instance protects the inventor from having his idea stolen, but the patent is worth nothing unless and until the associated inventor can find customers for his idea. The system thus encourages both the creation of new ideas and their dissemination. Patents that are issued wrongly, however, do not follow this pattern. A patent holder whose patent covers a technology that was already obvious to those skilled in the art has a strong incentive to sit quietly after the patent is issued, knowing full well that other parties will stumble onto that same obvious technology in time. When that happens, the patent holder can step forward, threaten litigation, and in the end extract royalties from infringers who neither knew of nor benefited from the patent holder's work. ${ }^{10}$ Sadly, a large and growing number of "patent trolls" today play this exact strategy, using patents on obvious inventions quite literally to tax legitimate business activity. ${ }^{11}$

For an argument that the presumption can be justified as a matter of history based on an analogy to land title, see Adam Mossoff, _ Cornell L. Rev. _ (forthcoming July 2007). Whether or not Mossoff is right as an historical matter, there seems no policy justification for a presumption of validity unearned by examiner expertise.

10. For an economic analysis of such holdup strategies, see Joseph Farrell \& Carl Shapiro, How Strong Are Weak Patents (Competition Policy Ctr., Univ. of Cal. at Berkeley, Paper No. CPC05-54, 2007), available at http://faculty.haas.berkeley.edu/shapiro/weak.pdf; Joseph Farrell \& Robert P. Merges, Incentives to Challenge and Defend Patents: Why Litigation Won't Reliably Fix Patent Office Errors and Why Administrative Patent Review Might Help, 19 BeRKELEY TeCH. L.J. 943, 952-60 (2004); Mark A. Lemley \& Carl Shapiro, Patent Holdup and Royalty Stacking, 85 TeXAS L. ReV. 1991 (2007); Carl Shapiro, Injunctions, Hold-Up, and Patent Licensing (Competition Policy Ctr., Univ. of Cal. at Berkeley, Paper No. CPC06-062, 2006), available at faculty.haas.berkeley.edu/shapiro/royalties.pdf.

11. In the computer and electronics industries, these non-practicing entities account for over a third of all patent lawsuits. Mark A. Lemley et al., Patent Trolls and Patent Pirates (vaporware 2007). 
What to do? One tempting idea is to increase PTO funding, making possible more rigorous up-front screening of patent applications. That would obviously help weed out bad patents, but the drawback is that most of the money would be wasted. As one of us pointed out years ago, most patents lie dormant after issuance. ${ }^{12}$ They claim technologies that ultimately fail in the marketplace. They protect firms from competitors who, for other reasons, never materialize. They are lottery tickets filed on the speculation that a given industry or invention will take off. Patents in these categories will never be read, never be licensed, and never be asserted in negotiation or litigation. Money spent perfecting these documents, then, is money thrown away. ${ }^{13}$ That obviously is unfortunate to the extent that those dollars are tax dollars. It is also unfortunate, however, if those dollars belong to patent applicants, because every dollar an applicant invests in the patent process is a dollar the applicant cannot spend in other ways promoting and developing the patented invention.

Our proposal, therefore, aims not to improve the overall quality of PTO review, but instead to change the presumption of patent validity to more accurately reflect the realities of current patent practice. The goal is to discourage the filing of bad but not good patents, ${ }^{14}$ and at the same time to empower the PTO to better distinguish between the two. Our overall point is not that patents should never be accorded a strong favorable presumption. It is instead that presumptions must be earned.

Specifically, we propose three related reforms: First, the strong "clear and convincing evidence" presumption of patent validity that today is accorded to every patent by default should be removed and replaced with a much weaker presumption that accused infringers could rebut under a "preponderance of the evidence" standard. With this weaker presumption in place, patent examiners

12. See Lemley, supra note 5.

13. This would not be true if competitors were nonetheless scared off by the mere existence of these patents. See Christopher Leslie, The Anticompetitive Effects of Unenforced Invalid Patents, 91 Minn. L. Rev. 101 (2006) (making this argument) But we are skeptical that competitors are frequently deterred by patents that simply sit on a shelf. In many industries, particularly information technology, large companies tend to ignore patents unless they are brought to the company's attention by the patent owner (and sometimes the companies ignore them even then). Not only do patent attorneys in these industries advise their clients not to read patents, see Mark A. Lemley \& Ragesh K. Tangri, Ending Patent Law's Willfulness Game, 18 BERKELEY TECH. L.J. 1085 (2003), and not to conduct a prior art search, see Bhaven N. Sampat, Determinants of Patent Quality: An Empirical Analysis, 3 (Sept. 2005) (unpublished manuscript), available at http:// siepr.stanford.edu/programs/SST_Seminars/ patentquality_new.pdf_1.pdf, but they even ignore letters that threaten suit, reasoning that if the patentee is serious it will either file suit or at least send a follow-up letter. See Mark A. Lemley, Ignoring Patents (working paper 2007). But cf. Josh Lerner, Patenting in the Shadow of Competitors, 38 J. L. \& Econ. 463 (1995) (reporting an empirical study of small biotech firms suggesting that they were deterred by patents held by competitors).

14 See also Matthew Sag \& Kurt Rohde, Patent Reform and Differential Impact, 8 Minn. J.L., Sci. \& Tech. 1 (2007) (suggesting this as a goal for patent reform). 
would still play their customary role in terms of evaluating claim language and ensuring that applicants comply with the patent system's many rules about the form and content of patent disclosures. Patent examiners would also continue to weed out the most egregious applications and to force inventors to commit up front to details about their claimed accomplishments, thereby limiting the risk that a patent holder will be able to strategically alter details during litigation. Patent examiners, however, would no longer themselves make a definitive ruling with respect to validity. Examiners, instead, would document their reasons for allowance, and those reasons should certainly be considered by later decision-makers, ${ }^{15}$ but there would be only a modest presumption that the examiner's validity analysis was, in fact, correct. Courts would be free to deem that presumption fully rebutted in cases where the evidence, on balance, ultimately suggests that patent protection is inappropriate.

Second, and in essence to fill the hole created by the first reform, either Congress or PTO officials should create a new opportunity for patent applicants to "gold-plate" their patents-funding and submitting to a vigorous review process in the PTO, and in return earning a significant presumption in favor of patent validity. The procedure would be entirely optional. Applicants who forgo it would still be able to defend their patents in court should that need arise. Applicants who opted for this approach, however, would enjoy surer protection. Courts would be allowed to consider evidence that was not considered by the examiner at the time of this intense review, but courts would need to overcome a significant threshold before being allowed to second-guess the PTO's evaluation of evidence that was in fact considered. In order to provide funding sufficient to actually run an intense evaluation, the fees associated with this supplemental review would have to be significantly higher than current fees. ${ }^{16}$ Those higher fees would discourage patent holders from too readily invoking the process, allowing applicants to sort their inventions into those that need extra review and those that don't. ${ }^{17}$

Finally, in addition to this proposed new form of PTO review, there are other procedures that result in reliable patent evaluation; either the courts or Congress should make available a presumption of validity in those settings as well. For instance, when a court or the United States International Trade Commission (ITC) evaluates a patent in the context of litigation, that evaluation should be accorded substantial deference in any later litigation involving the

15. Under current Federal Circuit case law, courts are required to ignore an examiner's statement of reasons for allowance. Salazar v. Procter \& Gamble Co., 414 F.3d 1342 (Fed. Cir. 2005). That rule makes no sense, and we think it should be reversed.

16. As is already the case today with respect to most other PTO procedures, reduced fees would be available to smaller entities.

17. Indeed, the PTO is already considering something similar, though the carrot they can offer under current law is not a stronger presumption of validity but accelerated examination. Changes to Practice for Petitions in Patent Applications To Make Special and for Accelerated Examination, 71 Fed. Reg. 36,323 (June 26, 2006), available at http://www.uspto.gov/web/offices/com/sol/notices/71 fr36323.htm. 
same patent. Similarly, when under current law a challenger requests that the PTO reexamine an issued patent, the results of that intense look should be given heavy presumptive weight in later judicial proceedings. If Congress adopts one of the many proposals that would create a post-grant opposition process, there again decisions made as part of that more intense review should be accorded deference by later decision-makers. ${ }^{18}$ Deference in each of these instances should be calibrated to match the strengths and weaknesses of the relevant first-round decision. For instance, the more adversarial the process, the greater the appropriate deference, because adversarial interactions are particularly good at bringing forward evidence and arguments. Similarly, the more time that passes between issuance and evaluation, the greater the deference, this time because delay means that there was more opportunity for reliable outsider evaluations to come to light.

In summary, the presumption of validity is today recognized too readily, built into a one-size-fits-all patent system where every application is given the same-necessarily sparse-review. The result is a counterproductive system where patents are wrongly issued and then vigorously enforced. Our proposal would recalibrate the presumption of validity to better account for the realities of patent review. The courts or the PTO itself must take the first and most important step: voluntarily ratcheting down the presumption that, by default, is accorded every patent upon issuance. Then Congress, the PTO, and the courts could combine to implement the second and third prongs, with Congress and/or the PTO creating new procedures through which presumptions could be earned, and the courts in turn recognizing tailored presumptions in any context where there is reason to believe that a prior decision-maker made a reliable decision. The net effect would be to reduce applicants' incentive to file undeserved applications in the first place, to reduce the disruption caused by any undeserved applications that might accidentally slip through, and at the same time to provide a greater degree of certainty to patentees who deserve it.

\section{THE PRESUMPTION TODAY}

Patent law's presumption of validity derives from the language of the U.S. Patent Act itself. Specifically, in section 282, the Act provides that "[t]he

18. Scholars have been debating the details of a possible post-grant opposition proceeding for years, and legislative proposals have been put forward several times, thus far to no avail. For a sense of the academic debate as well as links to some of the legislative proposals, see Mark D. Janis, Rethinking Reexamination: Toward a Viable Administrative Revocation System for U.S. Patent Law, 11 Harvard J.L. \& TeCh. 1 (1997); Robert P. Merges, As Many as Six Impossible Patents Before Breakfast: Property Rights for Business Concepts and Patent System Reform, 14 Berkeley TECH. L.J. 577 (1999); Craig Allen Nard, Certainty, Fence Building, and the Useful Arts, 74 InD. L.J. 759 (1999); J. H. Reichman, From Free Riders to Fair Followers: Global Competition Under the TRIPS Agreement, 29 N.Y.U. J. INT'L L. \& Pol. 11 (1997); John R. Thomas, Collusion and Collective Action in the Patent System: A Proposal for Patent Bounties, 2001 U. ILL. L. REV. 305 (2001). 
burden of establishing invalidity of a patent or any claim thereof shall rest on the party asserting such invalidity." 19 This language on its face sets an unobjectionable baseline: after issuance, the default outcome in litigation is a finding of validity, and a challenger must amass evidence before a patent can be declared invalid. The modern presumption of validity, however, goes troublingly farther. As courts apply the doctrine today, the only way to render invalid an issued patent is to present "clear and convincing" evidence that the patent was improvidently granted. This is a high evidentiary bar, and one that, in practice, often proves difficult for accused infringers to overcome. ${ }^{20}$

The court opinions that establish this rule do not explain the policies behind it. ${ }^{21}$ However, two such policies are readily apparent. First, the presumption of validity forces courts to defer to the expertise of the PTO, thereby avoiding redundant and possibly inferior second looks by the courts. Presumptions are used throughout the law for precisely this reason. If some initial decision-maker has made a decision about an issue, and if there is reason to believe that the decision is probably right, a presumption works to avoid wasteful reconsideration. This might in the aggregate reduce accuracy; but the point is that the first decision is sufficiently good that the odds of improving it are small and thus the costs of a second look are unwarranted. ${ }^{22}$

Second, to bring a patented technology to market, patent holders often must invest substantial resources in development and commercialization. The presumption of validity reduces the risk associated with those investments. A

19. 35 U.S.C. $\S 282$.

20. The statutory language was not always read this way. Indeed, prior to the formation of the Federal Circuit, courts varied considerably in terms of the degree of deference they would show, both by circuit and on the basis of how closely the patent examiner had considered the validity argument now being raised. See, e.g., Mfg. Research Corp. v. Graybar Elec. Co., 679 F.2d 1355 (11th Cir. 1982); NDM Corp. v. Hayes Prods., Inc., 641 F.2d 1274 (9th Cir. 1981); Lee Blacksmith, Inc. v. Lindsay Bros., Inc., 605 F.2d 341 (7th Cir. 1979) (all adopting the rule that only "considered art" was subject to the clear and convincing evidence presumption). The Federal Circuit, however, has consistently applied the high bar, see Connell v. Sears, Roebuck \& Co., 772 F.2d 1542 (Fed. Cir. 1983), and it continues to do so today. See, e.g., Kahn v. General Motors Corp., 135 F.3d 1472, 1480 (Fed. Cir. 1998) ("The presentation of evidence that was not before the examiner does not change the presumption of validity ...."); Ultra-Tex Surfaces, Inc. v. Hill Bros. Chem. Co., 204 F.3d 1360, 1367 (Fed. Cir. 2000). For a discussion of how the Federal Circuit changed the rules, see Donald S. Chisum, Patent Law $\S \_$; Don Martens \& Guy Perry, Reexamining the Clear and Convincing Standard of Proof, IPL Newsletter, Summer 1999, at 16.

21. For a detailed discussion of the early opinions establishing this uniform deference and their problems, see Lee Hollaar \& John Knight, Unclear and Unconvincing: How a Misunderstanding Led to the Heightened Evidentiary Requirement in Patent Litigation (May 20, 2007) (unpublished manuscript, available at http://digital-law-online.info/papers/ jk/unclear.pdf).

22. The presumption of validity in theory reduces court costs by reducing the incentive to litigate. An accused infringer has little reason to litigate if the presumption all but guarantees a win to the patent holder. In cases where litigation does occur, however, the presumption does not likely reduce costs; patent litigants today spend a fortune fighting over whether the presumption has been rebutted in each specific case. 
patent holder whose patent benefits from a presumption knows that, if his development and commercialization efforts turn out successful, he likely will have a valid patent that will empower him to exploit that success. The presumption thus encourages the patent holder to spend the necessary resources. Patent holders in the pharmaceutical industry, in particular, emphasize this benefit. In that industry, enormous expenditures are required after patent issuance, including expenditures related to testing and regulatory approval.

We do not quarrel with either of these rationales. The presumption of validity surely does at times reduce wasteful duplication of investigative efforts, and the presumption of validity also surely does encourage, under certain circumstances, patent holders to invest in development and commercialization. As discussed further below, however, the extent of these effects seems small. PTO review is so terse and imperfect that a later, second look is unlikely to be significantly redundant, and even less likely to increase the error rate. And while uncertainty regarding patent rights might discourage some types of investment, it would seem odd to focus too heavily on this effect, both because the presumption is not conclusive, which means that the validity and scope of a patent remain unclear even under current rules, ${ }^{23}$ and because patent uncertainty is only one of a million uncertainties facing a firm that is actually endeavoring to bring a patented invention to market. Thus, these rationales do not seem sufficient to justify the presumption as it exists today.

\section{A. Deference to the PTO}

Start with the first of these policy defenses: that deference to the PTO avoids redundant and likely inferior second looks. This argument is strong only if it is plausible to think that the PTO can, at the time of patent application, run a substantial and relatively reliable evaluative process. For reasons beyond the PTO's control, that seems unlikely.

We have already mentioned one problem: the budget. Several hundred thousand patent applications are filed every year, ${ }^{24}$ and those applications cover the full range of technologies-from breakthroughs that involve the human genome to innovative new designs for consumer electronics. Patent examiners who are assigned to evaluate those applications are chosen, in part,

23. As one of us has emphasized elsewhere, patents are probabilistic rights—not rights to exclude with certainty, but rights to try to exclude. See Mark A. Lemley \& Carl Shapiro, Probabilistic Patents, 19 J. ECON. PERSP. 75 (2005).

24. In fiscal 2005, for example, the PTO reported receiving the following: 384,228 conventional patent applications; 46,926 applications that were filed pursuant to special rules that apply to foreign filings; and 111,753 provisional applications that are, in essence, place holders that can later mature into conventional applications. See U.S. PATENT \& TRADEMARK Office, Performance And Accountability Report for Fiscal Year 200518 (2005), available at http://www.uspto.gov/web/offices/com/annual/2005/ 2005annualreport.pdf. 
because they have backgrounds roughly related to the technology at hand, but examiners are rarely experts on the precise details of the relevant invention. Thus, to evaluate an application, an examiner not only has to read the frequently voluminous documentation submitted by the applicant, but also must use computerized databases and other available sources to learn about the state of the art. The examiner obviously also has to interact with the applicant's lawyers and document any decisions ultimately made. Strikingly, examiners are asked to do all of this in what turns out to be an average of between sixteen and seventeen hours; ${ }^{25}$ and those hours are spread over what is often a three- to four-year period. ${ }^{26}$ Given these numbers, it is hardly a surprise that bad patents routinely slip through.

To do more, however, would be enormously costly. Suppose, for example, that the PTO were to hire actual industry experts to participate in patent review, for instance hiring an expert on digital camera lens technology when a patent on such a lens was filed. Assume that these experts could evaluate the invention, identify relevant prior art, and communicate their conclusions to the patent examiner in forty hours total, and that these experts would be willing to do all that while being paid a very modest expert wage of $\$ 200$ per hour. Ignoring both overhead and the salary owed to the patent examiners themselves, the aggregate costs of evaluating one year's worth of patent applications in this manner would top out at well over $\$ 3$ billion. $^{27}$

Now, admittedly, if patents were reviewed this aggressively, it is likely that fewer patent applications would be filed. It takes time and money to prepare an application, and applicants would be less likely to do that if the likelihood of patent issuance were low. Some applicants would similarly be dissuaded from applying if application fees were raised to cover fully the actual costs of rigorous patent review. Nevertheless, even a non-trivial reduction in the application rate would leave the basic numbers problem intact. Patent evaluation is scientific review at an extraordinary scale, and it will necessarily be flawed unless and until applicants, the government, or both are willing to pay a hefty price. (And remember, we do not advocate paying this price, for the simple reason that most patents will still never be read, never be litigated, and never be licensed, and so money spent here really is money wasted. $)^{28}$

Another limitation on the extent and quality of PTO review is the fact that early patent review is not-and as a practical matter cannot be-adversarial. Adversarial processes tend to produce good evaluative information. The court system, for instance, is thought to work in large part because in every case there are opposing parties arguing for different outcomes, and thus all the judge and

25. See Thomas, supra note 18 , at 314 .

26. See Kristen Osenga, Entrance Ramps, Tolls, and Express Lanes-Proposals for Decreasing Traffic Congestion in the Patent Office, 33 FLA. ST. U. L. REV. 119, 130 (2005).

27. Cf. Lemley, supra note 5, at 1508-09 (estimating additional costs to double the amount of time each examiner-who makes significantly less than $\$ 200$ per hour-spends on an application at $\$ 1.52$ billion).

28. See id. at 1510-11. 
jury need do is evaluate the alternatives rather than identify arguments and weaknesses themselves. ${ }^{29}$ Patent review does not benefit from this sort of competitive dynamic, however. Instead, the only parties that participate in the initial process of patent review are the applicant, the applicant's attorneys, and the examiner. This unavoidably yields an information-poor process. Bluntly, no matter how good the examiner, no examiner will ever know as much or be as motivated as a true market rival.

Adversaries are not welcome in the process today in part because the patent system tries to protect applicants from having their ideas leak out too early. This is important to applicants whose applications are ultimately rejected, because after rejection these applicants will want to rely on secrecy to protect their unpatented work. Even if society were to abandon the goal of protecting unsuccessful applicants, ${ }^{30}$ however, it would still be difficult to implement a genuinely adversarial application process. After all, it would be an enormous burden on industry if every firm had to monitor filings at the PTO and then participate in any relevant application process. This is especially true in the information technology industries, where perhaps 100,000 patents issue every year and where a given commercial product can implicate hundreds and perhaps even thousands of those patents. Worse, participation can be a doubleedged sword. A participating firm would be identifying itself as a target for later litigation in the event the patent is issued, and such a firm would at the same time be acknowledging awareness of the patent and hence exposing itself to later charges of willful and/or contributory infringement. ${ }^{31}$ Moreover, adversarial participation would be implausible in instances where, at the time of patent evaluation, the relevant market was still in its infancy. In such cases, firms that might ultimately be key competitors would not even exist at the time of patent review, let alone realize the need to fight the application or have the

29. Among the abundant literature on the adversary system and its benefits and costs, see Geoffrey C. HaZARd, Ethics in the Practice of LAW 121 (1978); David Luban, The Adversary System Excuse, in THE GOOD LAWYER: LAWYERS' ROLES AND LAWYERS' ETHICS 83, 94 (David Luban ed., 1984); Stephen A. Saltzburg, Lawyers, Clients, and the Adversary System, 37 MerCer L. Rev. 647, 656 (1986); cf. Lon Fuller, The Adversary System, in TALKS ON AMERICAN LAW 30, 31 (Harold J. Berman ed., 1961) (discussing the importance of "partisan zeal" in achieving a fair outcome). But cf. Stephen McG. Bundy \& Einer Richard Elhauge, Do Lawyers Improve the Adversary System? A General Theory of Litigation Advice and Its Regulation, 79 CAL. L. REV. 313 (1991) (asking the distinct question whether legal advice benefits or harms the adversary system).

30. To some extent Congress did this several years ago when it required publication of most patent applications eighteen months after they are filed. The bill actually passed merely required those who file counterpart applications abroad to publish their applications here, however. 35 U.S.C. $\S 122$ (b). Because the rest of the world already required publication at eighteen months, the practical effect of this new statute was negligible-it merely required publication in the U.S. of applications that were already being published abroad.

31. On the current definition of willful infringement and its problems, see, e.g., Lemley \& Tangri, supra note 13; Matthew D. Powers \& Steven C. Carlson, The Evolution and Impact of the Doctrine of Willful Patent Infringement, 51 SYRACUSE L. REV. 53, 102-04 (2001). 
resources to do so. Finally, were adversarial interactions possible, they would raise the costs of patent review, and even that is unattractive given that both the government and the dueling parties likely can do better things with their cash than invest in grueling combat every time a patent application is filed.

The absence of third-party information is yet another constraint that calls into doubt the quality of early patent review. One of the central questions raised in patent review is whether the purported invention was obvious to those skilled in the art at the time it was supposedly invented. ${ }^{32}$ Obviousness is difficult to judge at the time of patent application. Over time, however, objective evidence bearing on obviousness comes to light. Was the invention a significant market success? Did competitors copy the technology after it was unveiled? Did other inventors independently accomplish the same thing at approximately the same time? Was the invention greeted with praise or skepticism by industry experts? ${ }^{33}$ This and comparable information is not available at the time a patent application is first filed, and hence it cannot contribute to the accuracy of early patent review. By the time of a second look, however, secondary evidence along these lines can be introduced. Indeed, courts today are obligated to consider this sort of information, albeit subject to the presumption of validity. ${ }^{34}$

In short, to the extent that the presumption of validity is justified on an intuition about the quality or extent of initial patent review, that justification falls flat. The PTO simply cannot engage in particularly rigorous or accurate initial patent review, ${ }^{35}$ and thus, although the PTO process is certainly helpful

32 See, e.g., KSR Int'l Co. v. Teleflex, Inc., 127 S. Ct. 1727 (2007).

33. For discussion of these "secondary considerations" of nonobviousness, see, e.g., Greenwood v. Hattori Seiko Co., 900 F.2d 238, 241 (Fed. Cir. 1990); Hybritech Inc. v. Monoclonal Antibodies, Inc., 802 F.2d 1367 (Fed. Cir. 1986); Rochelle Cooper Dreyfuss, The Federal Circuit: A Case Study in Specialized Courts, 64 N.Y.U. L. REV. 1 (1989); Edmund W. Kitch, Graham v. John Deere Co.: New Standards for Patents, 1966 SuP. CT. Rev. 293 (1966); Robert P. Merges, Commercial Success and Patent Standards: Economic Perspectives on Innovation 76 CAL. L. REV. 803 (1988).. With the exception of Dreyfuss, the commentators cited are critical of the commercial success factor as evidence of nonobviousness, though they agree that other factors are important.

34. Objective information such as this is also important because it helps combat hindsight bias. There is always in the patent system the concern that a decision-maker will see the purported invention and immediately think that it was obvious, even if no one had thought of it before. This problem is particularly troublesome in litigation because, by the time litigation begins, the patented invention will typically have been out in the world for many years and thus seem familiar. Objective evidence helps decision-makers combat this natural but troubling tendency.

We focus in the text on reasons why, as a matter of first principles, PTO review cannot work. Our point is that even a benevolent dictator would have trouble making PTO review effective, because early stage evaluations of every application that comes in the door are too costly, insufficiently adversarial, and come too early in time for there to be adequate reliable third-party information about invention quality. If these obstacles were somehow removed, there would then be an additional layer of practical and bureaucratic problems to addressstructural problems about how examiners are hired, how examiner work is evaluated, and the degree to which an examiner can ultimately and decisively reject a patent application. See, e.g., Mark A. Lemley \& Kimberly A. Moore, Ending Abuse of Patent Continuations, 84 B.U. L. REV. 63 (2004) (discussing the rules that today allow an applicant to persevere 
and revealing, it does not on any measure warrant the heavy deference that it is accorded today.

\section{B. Patent Certainty}

The second policy rationale in favor of the presumption of validity is that the presumption reduces uncertainty and thereby increases a patent holder's incentive to invest in the development and commercialization of his patented technology. We are sympathetic to the desire for certainty, but we doubt that it alone can justify the presumption.

For starters, note how odd it would be to emphasize stability in the context of the presumption of validity, given how little weight stability is accorded almost everywhere else in patent practice. Consider, for example, the rules that govern when a court determination regarding patent validity binds later litigants. A patent holder who successfully defends patent validity in the context of a first infringement suit must start afresh when he sues a second infringer. Again, the patent holder must rebuff arguments that the patent was improvidently granted. Again, the patent holder must establish his desired claim constructions. ${ }^{36}$ A patent holder whose patent is found invalid in some first case, by contrast, is barred from ever again enforcing that patent. ${ }^{37}$ If there is some randomness in litigation, the result here is to shift significant uncertainty onto patent holders. A lucky draw has implications only for the specific litigation at hand. An unlucky one has implications for every future interaction.

The interpretive rules under which patent claims are analyzed similarly undermine patent certainty, not because of their substance but because they are constantly in flux. One minute the PTO is approving claim language where some new apparatus is described in part by articulating how the apparatus should be used; the next, the Federal Circuit retroactively declares all such claims to be so unclear as to be invalid. ${ }^{38}$ Similarly, one minute the practice of altering claim language during patent prosecution is seen as a natural part of the give-and-take between applicant and examiner; the next, the Federal Circuit and the Supreme Court combine to retroactively change the rules, this time announcing that almost every such language alteration will be construed as a

indefinitely even in the face of repeated rejections by his examiner). These problems are important; but we do not focus on them here because they are not unavoidable difficulties associated with PTO review. That is, these problems could be solved by the appropriate reforms; the financial and informational problems, by contrast, cannot be.

36. There is some question whether a prior court's claim construction, as a legal ruling, is binding in subsequent cases involving the patent. See, e.g., Hilgraeve Corp. v. Symantec Corp., 265 F.3d 1336, 1341-42 (Fed. Cir. 2001) (raising but not deciding this issue).

37. Blonder-Tongue Labs., Inc. v. Univ. of Ill. Found., 402 U.S. 313 (1971).

38. See IPXL Holdings, L.L.C. v. Amazon.com, Inc., 430 F.3d 1377 (Fed. Cir. 2005) (holding mixed system-method claims invalid) 
concession that limits patent scope. ${ }^{39}$

And this is just the tip of the iceberg. The Federal Circuit regularly reverses lower court claim construction decisions. ${ }^{40}$ The Supreme Court recently threw into disarray the previously established rule that patent holders were entitled to injunctive relief if they could prove infringement of a valid patent. ${ }^{41} \mathrm{~A}$ patent can be held invalid because someone uncovers "secret" prior art-art that was not public at the time of invention, but that is nevertheless admissible in court under one of several special exceptions. ${ }^{42}$ We provide these examples not to question whether stability has value (of course it does), nor even to criticize these specific rules and decisions, but instead to point out how disingenuous it would be to put stability on a high pedestal in just this one context. The lesson from patent law more generally seems to be that stability is desirable, but the patent system is willing to pay only a remarkably modest price to achieve it.

One reason that patent law is so willing to sacrifice stability is that, in practice, legal uncertainty is only one among many types of uncertainty in play. Pharmaceutical companies, for instance, admittedly worry about the strength of their patent portfolios. But a little less certainty there is unlikely to radically alter firm behavior given that success in the pharmaceutical industry critically depends on other, unavoidable uncertainties such as the uncertainty associated with FDA review and the very real risk that, because of some unexpected side effect, a blockbuster drug will suddenly lose all of its value and even become a source of devastating legal liability. Similarly, small firms and start-ups face enormous risks above and beyond the risks associated with patent validity. Indeed, every venture capitalist in the country can list dozens of innovative start-ups that today hold presumptively valid patents but have yet to generate a penny of revenue. Again, patent uncertainty is important, but its importance ought not be overstated.

Yet another reason to question whether a desire for certainty is enough to justify the presumption of patent validity is the simple fact that the presumption disproportionately helps patents for which validity would otherwise be in doubt. A patent that is clearly valid does not much benefit from a presumption of validity. Even without a presumption, the relevant patent holder can be

39. See Festo Corp. v. Shoketsu Kinzoku Kogyo Kabushiki Co., 234 F.3d 558 (Fed. Cir. 2000) (holding that a narrowing amendment precludes reliance on the doctrine of equivalents altogether), vacated, 535 U.S. 722 (2002) (holding that a narrowing amendment precludes reliance on the doctrine of equivalents except in very narrow, specified circumstances). For discussion of this particular patent issue, see Doug Lichtman, Rethinking Prosecution History Estoppel, 71 U. Chi. L. Rev. 151 (2004).

40. See Kimberly A. Moore, Are District Court Judges Equipped to Resolve Patent Cases?, 15 HARV. J.L. \& TECH. 1 (2001); Kimberly A. Moore, Markman Eight Years Later: Is Claim Construction More Predictable?, 9 LEWIS \& CLARK L. REV. 231, 239 (2005) (stating that the Federal Circuit rejects at least one claim construction in $37.5 \%$ of cases, and reverses or vacates $29.7 \%$ of cases on claim construction).

41. See eBay Inc. v. MercExchange, L.L.C., 126 S. Ct. 1837 (2006).

42. See, e.g., 35 U.S.C. § 102(e), (g). 
reasonably confident that the patent will survive court challenge. ${ }^{43}$ A patent holder relying on a suspect patent, by contrast, gains significant ground by virtue of a strong presumption. Thus, to the extent a presumption encourages investment, it seems to encourage investment in the wrong inventions. The patent system is designed to encourage investment in technologies that are genuinely new, not technologies that are likely redundant to things society knew before.

There are still more problems with the view that the presumption of validity is justified on the ground that patent holders need legal certainty. For instance, there is an academic literature that suggests that the last marginal increase in patent certainty comes at an enormously high cost to society, in essence because a confident patent holder can be particularly aggressive when it comes to negotiating licensing deals or settling litigation. ${ }^{44}$ There is also a literature suggesting that firms have other means by which to increase certainty, such as acquiring large numbers of overlapping patents and in that way creating a somewhat-diversified patent portfolio. ${ }^{45}$ Thus, a justification that explains the presumption of validity on the ground that it beneficially increases certainty is precarious, at best. Certainty is important, but certainty is not a good reason to endorse the current presumption, especially given the obvious costs the presumption today imposes.

\section{LAYERED PRESUMPTIONS}

To this point, we have argued that PTO review as it currently stands is not sufficiently intense or accurate to warrant deference, and that, while deference does somewhat reduce uncertainty, the case for reducing uncertainty in this manner is weak. Moreover, as we pointed out in the Introduction, the presumption of validity is affirmatively unattractive to the extent that it locks in mistakes that would otherwise be corrected by presumption-free litigation, and further unattractive to the extent that it encourages applicants to submit questionable applications in the hope that those applications might slip through and then benefit from the presumption.

With that background in place, we offer three proposed reforms.

43. It is always possible that a wayward judge and a wayward jury will combine to wrongly invalidate a patent that should have been held valid. But that possibility exists even with the presumption of validity. The only way to eliminate legal error entirely would be to eliminate judicial review of validity altogether, and that would increase the harm from PTO error.

44. See, e.g., Ian Ayres and Paul Klemperer, Limiting Patentees' Market Power Without Reducing Innovation Incentives: The Perverse Benefits of Uncertainty and NonInjunctive Remedies, 97 MicH. L. REV. 985 (1999).

45. See, e.g., Gideon Parchomovsky and R. Polk Wagner, Patent Portfolios, 154 U. PA. L. REV. 1 (2005). 


\section{A. Eliminate the Clear and Convincing Evidence Presumption}

First, the PTO should disclaim the strong presumption currently recognized in favor of its work. The presumption is for the most part a judicially created rule of deference under which courts acknowledge what they understand to be the PTO's desire to have its earlier evaluation respected. The PTO should speak up and disavow that desire. Specifically, the PTO should instruct patent examiners to do exactly what they do today but also to include, upon patent issuance, boilerplate language welcoming the courts to revisit the question of patent validity in the event an issued patent ends up in litigation. The PTO obviously cannot, and in any event should not, reject the statutory baseline; that is, challengers should still have the burden of bringing forward evidence that the patent was wrongly issued. ${ }^{46}$ However, the PTO should politely decline the heavier presumption that courts today recognize as a matter of course. To the extent that the PTO has valuable arguments and insights to contribute, it can do that by influencing how the issued patent reads and what documents are in the file. The PTO need not wield its influence through the use of a heavy presumption. ${ }^{47}$

It is admittedly hard to know whether a change of this sort would be enough to bind the courts. Patent examiners sometimes write notes to the file wherein they explain why they let a particular patent be issued, and yet patent courts today knowingly - and in our view indefensibly_-basically ignore those communications. ${ }^{48}$ It is possible the same would hold true for a PTO policy such as the one we advocate. That said, it would seem untenable as a matter of administrative law for the courts to strongly "defer" to an agency decision in a case where the agency itself explicitly requests a lighter touch. ${ }^{49}$

All this is admittedly contentious ground, and our proposal might

46. 35 U.S.C. $\$ 282$.

47. Indeed, it is worth noting that when the PTO itself considers the validity of the patents it has already issued, in both reissue and reexamination proceedings, it ignores the presumption of validity and reconsiders the patent without any deference to the first determination. See 35 U.S.C. $\S \S 251$ (reissue applications treated the same as original applications for patent), 305 (ex parte reexamination), 314(a) (inter partes reexamination).

48. See, e.g., Salazar v. Procter \& Gamble Co., 414 F.3d 1342 (Fed. Cir. 2005). Under Salazar, examiner statements of reasons for allowance-as opposed to applicant statements clearly disavowing claim breadth-are given no weight.

49. The Supreme Court held in 1999 that the Administrative Procedure Act applies to the PTO. Dickinson v. Zurko, 527 U.S. 150 (1999). For discussions of deference to the PTO under the APA, see, e.g., Stuart Minor Benjamin and Arti K. Rai, Who's Afraid of the APA? What the Patent System Can Learn from Administrative Law, 95 Geo. L.J. 269 (2007); Craig Allen Nard, Deference, Defiance, and the Useful Arts, 56 OHIO ST. L.J. 1415 (1995); Orin S. Kerr, Rethinking Patent Law in the Administrative State, 42 WM. \& MARY L. REv. 127 (2000). The PTO does not have substantive rulemaking authority, however, so if PTO statements to this effect are to have force it must be in the context of particular determinations of patent validity, not a general rule interpreting section 282 of the Patent Act. 
ultimately need to be implemented either via statutory amendment ${ }^{50}$ or by judicial reinterpretation of the existing statute and its associated case law. ${ }^{51}$ The latter approach is more feasible than it might seem; not only is the clear and convincing evidence standard a judicial creation, but the uniform standard is of recent vintage. Before the 1980 s, courts generally did not give substantial deference to PTO validity decisions in cases where the arguments made in court differed from the ones the examiner had expressly considered. ${ }^{52}$ And while the Federal Circuit has long been the last word on patent issues, the Supreme Court has recently taken a more active role in reviewing substantive patent rules. ${ }^{53}$ The illogic of the clear and convincing evidence presumption, and the fact that it departs from the prior rule in many other circuits, may make it ripe for Supreme Court review should the Federal Circuit fail to act. Judicial reform may also be desirable because, unlike PTO reform, it would apply not only to new patents but also to existing patents.

If the current strong presumption of validity is in any of these ways successfully removed, the PTO would still play a central role in the patent process. Examiners would still weed out obviously flawed requests, they would continue to wield significant influence over claim language, and they would still generate a paper trail that might later limit an applicant's ability to make self-serving arguments about what was claimed, what was invented, and when. The only difference is that, with respect to patent validity, issued patents would not benefit from the heavy thumb courts today put on the scale in favor of the PTO's original validity decision. As we have argued here, that original decision will often be inaccurate, not due to any failing on the part of patent examiners, but instead due to the extraordinary budgetary and informational constraints under which initial patent review is by necessity accomplished.

50. Section 282 of the Patent Act currently states that "the burden of establishing invalidity of a patent or any claim thereof shall rest on the party asserting such invalidity." Congress could add a second sentence here that would clarify the extent of that burden, for example, "That burden is met whenever a party brings forward new evidence sufficient to show that, more likely than not, the patent would not have been granted had the patent examiner been aware of the new evidence at the time of initial patent review."

51. For an argument for the latter course, see Lemley, Rational Ignorance, supra note 5, at 1528-29; Benjamin \& Rai, supra note 47, at _..

52. See, e.g., Mfg. Research Corp. v. Graybar Elec. Co., 679 F.2d 1355 (11th Cir. 1982) (adopting the rule that the clear and convincing evidence presumption applies only to prior art considered by the examiner); NDM Corp. v. Hayes Prods., Inc., 641 F.2d 1274 (9th Cir. 1981) (same); Lee Blacksmith Inc. v. Lindsay Bros., Inc., 605 F.2d 341 (7th Cir. 1979) (same).

53. See John F. Duffy, The Festo Decision and the Return of the Supreme Court to the Bar of Patents, 2002 Sup. CT. Rev. 273. Since Duffy's article was written, the Court has gotten more involved, and indeed had more patent cases on its docket in 2006 than in any year since 1965. But cf. Mark D. Janis, Patent Law in the Age of the Invisible Supreme Court, 2001 U. ILL. L. REv. 387, 387 (noting only a year before the onslaught began that the Supreme Court avoided patent cases). 


\section{B. Gold-Plated Patents}

Second, Congress should create a new, much more rigorous patent review process that would be run by patent examiners and that would be entirely voluntary. ${ }^{54}$ This supplemental review would be available only during prosecution-more on that below-and the fees associated with it would be sufficiently high that examiners would have the funding necessary not only to spend at least one full month researching each purported invention, but also to hire relevant outside experts to assist in that process. ${ }^{55}$ In addition, applicants who trigger this process would themselves be obligated to conduct a thorough search for prior art and submit the results of that search to the patent examiner, thus giving the examiner and the outside experts a good starting point for their work. Applicants would also obligated to submit with each piece of prior art an explanation as to why that prior art does not preclude patentability, in that way reducing the likelihood that an applicant can simply bury a damaging reference in a large pile of disclosures. ${ }^{56}$

Patents that survive the supplemental review process would earn and therefore be accorded a strong presumption of validity. Specifically, courts would not be allowed to second-guess decisions based on any prior art that the patent examiner actually considered during this more intense review, and even new art would be considered only if it could first be shown not to be redundant to materials already reviewed. Structuring the presumption this way creates an incentive for applicants to look for and show the examiner the most relevant prior art. Only art seen by the examiner could trigger a conclusive presumption, and so applicants would want the examiner to see as much prior art as possible. ${ }^{57}$ The only constraint from the applicant's perspective would be the obvious one: the applicant would not want to share so much prior art that the examiner would think the purported invention is not actually innovative.

54. If Congress does not act, the PTO could implement a similar procedure. Indeed, it is already talking about something of this sort. See supra note 15 . If the PTO implemented it, it would be up to the courts to give a correspondingly stronger presumption of validity to these more thoroughly vetted patents.

55. The goal of using outside experts is to make sure the PTO has the technical knowledge in the specific field necessary to understand how a person having ordinary skill in the art would view the application. Outside experts are not experts in patent law, and it would be unwise to delegate to them authority over the ultimate issues ("is the invention obvious?").

56. $C f$. Changes To Information Disclosure Statement and Other Related Matters, 71 Fed. Reg. 38,808, 38,810 (July 10, 2006) (to be codified at 37 C.F.R. pt. 1), available at http://www.uspto.gov/web/offices/com/sol/notices/71fr38808.pdf (proposing to require applicants submitting more than twenty pieces of prior art to explain the relevance of each piece).

The rule extending the conclusive presumption to duplicative art will both prevent applicants from having to submit duplicative art to the examiner and will prevent accused infringers from avoiding the presumption by finding a reference that says the same thing in a slightly different way. 
As is the custom already today with respect to most PTO fees, fees for this procedure would be set such that individual inventors and smaller entities would be given a break on price. The fee would remain intentionally high, however, because a high fee would discourage applicants from invoking the procedure lightly, and that would drive most of the work of patent review to other-and hopefully even more reliable — processes. Put differently, the high fee here would be a selection mechanism that would force applicants to credibly distinguish patents that for one reason or another ought to be evaluated early from those that can instead wait for later (ideally adversarial) procedures such as patent litigation, inter partes reexamination, and post-grant opposition.

This supplemental review would be available only during patent prosecution. Like the high fee discussed above, the idea here is to channel most patent review to other, and likely more reliable, procedures. That is, this window is intentionally tight, designed to make the process available only in those comparatively rare instances where a patent applicant knows early on that certainty would for some reason be particularly helpful. Patents that do not fit into that category-including what some have called "lottery ticket" patents ${ }^{58}$ — would, if ultimately determined to be valuable, thus end up being evaluated by patent litigation, inter partes reexamination at the PTO, or postgrant opposition. This again is by design. These other procedures are adversarial and hence likely to be more accurate than even a well-funded process that involves only the applicant, his lawyers, and the patent examiner.

Creating a second tier of patent applications might serve another purpose as well-allowing patent applicants to signal to the marketplace which of their inventions they consider the important ones. ${ }^{59}$ Our mechanism relies on the fact that many applicants have a pretty good idea up front which applications are likely to be most valuable to them. ${ }^{60}$ Gold-plating patents will not only let the PTO harness this private information, but may enable the market to benefit from it as well.

\section{Deference to Adversarial Determinations}

Third, and relatedly, there are already today a number of moments in the existing patent process during which a decision-maker takes a hard look at the merits of an issued patent. If patents are accorded only a featherweight presumption as a matter of course, and if very few patents earn a greater

58. F.M. Scherer, The Innovation Lottery, in EXPANDING THE BOUNDARIES OF InTEllectual Property: InNOVATION Policy fOR THE KNOWLEDge SOCIETy 3 (Rochelle C. Dreyfuss et al. eds. 2001); cite Dennis Crouch paper.

On patent signaling, see, e.g., Clarisa Long, Patent Signals, 69 U. Chi. L. Rev. 625 (2002). Note that the private market could provide other ways to credibly signal this information. Indeed, private solutions might be better, for instance if a private alternative ${ }_{60}$ could be even more rigorous or reliable than a PTO-run gold-plating process.

See John R. Allison et al., Valuable Patents, 92 Geo. L.J. 435 (2004). 
presumption by participating in gold-plated review, then additional weight could be recognized in support of patents that survive these other types of evaluation. For example, some issued patents are returned to the PTO after issuance and are reevaluated through an adversarial process known as inter partes reexamination. This is an evaluation to which some deference is appropriate. ${ }^{61}$ It involves the applicant and a rival; it typically takes place several years after the application was first filed; and the only patents subject to this procedure are patents specifically targeted by a complainant and accepted for review by the PTO. Similarly, decisions made in litigation or in the context of a hearing at the International Trade Commission (ITC) should be accorded a substantial degree of deference. Under current law, if a court or the ITC finds a patent valid and infringed, that finding does not officially increase the presumption of validity accorded the relevant patent; ${ }^{62}$ but that is because a strong presumption of validity is already in place even prior to the case. With that prior presumption gone, it would be appropriate to introduce a new presumption that would require courts to defer to any reliable decision made as part of these earlier adversarial processes. ${ }^{63}$

Proposals are afoot to add still more opportunities for merit-based patent reevaluation. Decisions made in these contexts too should be entitled to deference. For example, many commentators (and members of Congress in both parties) have called for the introduction of a post-grant opposition proceeding that would allow potential infringers to bring a patent back to the PTO for a second look. ${ }^{64}$ If those proposals are adopted, post-grant opposition would be the type of rigorous review that would warrant an eventual

61. Some deference is appropriate, but not the complete res judicata effect the law currently recognizes. See 35 U.S.C. § 315(c).

There be some effect in practice, however, as factfinders might find themselves inclined to defer to the decisions of other factfinders.

63. Our overall theme here is that the presumption of validity should be tailored to the reality of patent review, and that obviously applies to decisions made in court and at the ITC just as to decisions made at the PTO. Thus, presumptions would not be appropriate to the extent a later court believes that the earlier litigation was a sham, or to the extent that important information was for some reason not available during the prior evaluative process. Put another way, one design issue here is to make sure that patent holders do not have too strong an incentive to sue weak defendants first in the hope of being awarded a presumption.

64. See, e.g., H.R. 2795, 109th Cong., 1st Sess. (2005). See also supra note 8 (collecting academic commentary). It is important to design a post-grant opposition system carefully, with an eye toward strategic behavior by both patentees and accused infringers. For instance, as the procedure is described in some of the literature, a strategic infringer could abuse the process by triggering post-grant opposition merely as a tactic to drain a small patent-holder's resources. To avoid this, there should be limits on both the number of post-grant oppositions and the novelty of the issues raised, and perhaps a provision for fee shifting. At the same time, other proposals would allow post-grant opposition only within the first nine months after a patent issues. That would render the procedure largely useless, because in many situations the firms that would challenge a given patent are not even going to be in business at the nine month mark, let alone know that the relevant patent is important enough to warrant the expense and investment associated with post-grant opposition. 
presumption in its favor. ${ }^{65}$ (Inside the PTO, there would be no deference to the PTO's own initial decision to issue the patent, just as there is no deference today in a reissue or reexamination proceeding. If a patent survives post-grant opposition, however, the courts should presume the correctness of any factual findings specifically made as part of this adversarial process, just as we suggest they should for gold-plated patents.) The touchstones-met here and in our previous examples - are, again, some combination of an adversarial inquiry, an inquiry that applies to a small enough number of patents that it can be sufficiently well funded, and an inquiry that occurs late enough in a patent's life that some external information about the technology is available.

The theme that unifies our proposals is the need to better harness information that currently rests in private hands. The PTO needs help in assessing validity, but to make that assessment efficiently it also needs help in deciding which applications are worth the effort. Patentees have some of this information, both about importance and about validity, and allowing them to opt into special scrutiny will draw it out. Competitors have some of this information as well, and both post-grant opposition and litigation will elicit it. Further, post-grant opposition and litigation will elicit that information through the adversarial process, which we think far superior to even the best-intentioned government bureaucracy as a mechanism for finding truth. Finally, neutral experts have some of this information, and we support proposals to give examiners (through some sort of outside search or peer review process) and the courts (through the mechanisms of expert testimony and consideration of objective evidence of nonobviousness) greater ability to seek this information as well.

\section{OBJECTIONS}

We expect five primary objections to our proposal: it might harm cashstrapped inventors; it might make litigation more costly; it might shift the burden of determining patent validity to courts, which lack the necessary expertise; it might be too easy to get a gold-plated patent; and presumptions are just words anyway, so all this is much ado about nothing. We consider each objection in turn.

\section{A. Layered Presumptions Favor Patent Applicants Who Have Adequate Resources Over Individual Inventors and Start-ups}

One part of our proposal involves a new, intensive PTO procedure through which an applicant could ultimately earn a presumption of validity. This 
procedure would be expensive by design, both because the PTO would need money to run that intense review and because a high fee would discourage applicants from lightly requesting this procedure. A natural concern is that individual inventors and small entities will not be able to afford the fee, and that, as a result, these parties will in essence be relegated to a second-class patent system where patents must be defended from scratch in court. ${ }^{66}$ In response, we have already suggested that the fee schedule ought to offer a price break for smaller entities, in much the same way that the PTO currently offers a small-entity discount on the fees associated with filing a patent application. Still, this is a serious objection that warrants further discussion.

The truth of the matter is that almost any change designed to improve the quality of patent review will hurt cash-constrained applicants, because almost any change will end up costing more money. If patent examiners commit to spending twice as much time on each application during the normal review process, for example, patent fees will go up. If patent law changes to require that applicants conduct their own prior art searches prior to applying for patent protection, that extra cost will again sting. If post-grant opposition procedures are created by statute, patent holders who are dragged into those proceedings will need to hire lawyers to defend their patents, again resulting in new costs. Against this backdrop, our proposal is comparatively attractive, not simply because we can dampen any harm by reducing the fee for smaller entities, but, because a cash-starved firm can choose not to participate in the new procedure. Yes, that would make any ultimate dispute over patent validity more precarious, but validity disputes are rare in the patent system. Remember, most patents are never read, never licensed, and never litigated. Besides, even a firm that expects litigation might prefer to put off investing in that litigation and instead focus in its early days on marketing, commercialization, and other investments that are likely more important determinants of long-run success.

Finally, we note that under the current system, a patentee who wants to enforce its patent will pay legal fees that run into the millions of dollars. Patentees who opt to pay more for a stronger presumption of validity are likely to be those who will ultimately enforce their patents in court; asking a patentee who plans to pay millions to lawyers to pay perhaps $1 \%$ of that to strengthen its patent from the get-go does not seem unreasonable.

\section{B. Reducing the Presumption of Validity Will Encourage Frivolous Validity Challenges and Wasteful Searches for Obscure Prior Art.}

Accused infringers spend exorbitant amounts of money searching for prior art that might disprove the originality of the asserted patent. The necessary prior art might be a doctoral thesis, written in Greek, archived in a government library, and completely unnoticed by the literature or industry. Nevertheless, if

66 For a detailed expression of this concern, see Michael Meehan, An Economic Approach for Increasing Certainty in the Patent System (working paper 2007). 
the liability associated with a finding of infringement is large enough, an accused infringer will gamely join the hunt. The trade-off for the infringer, after all, is a comparison between the costs of the search and the costs associated with losing the case. That balance will often fund a significant, indeed an excessive, search budget.

Any legal change that weakens the presumption of patent validity might amplify this incentive to search. The reason is that, the lesser the presumption, the greater the likelihood that the infringer will be able to find a piece of prior art sufficient to invalidate the patent. Whether that is a social benefit or a social harm depends on the circumstances. Invalidating patents that should not have been granted is clearly worthwhile. The relevant patent is stopped from further disrupting the industry, and, anticipating this, future patent applicants are dissuaded from filing overbroad patent applications in the first place. Allowing ridiculously obscure prior art to invalidate a patent, by contrast, seems a mistake. If society knew of an invention only in the very formal sense of there being a doctoral thesis, written in Greek, buried in a remote library, then the relevant patent probably ought not be invalidated even if a particularly resourceful litigant ultimately finds that document. The patent holder, after all, really did bring new and worthwhile information into public use.

In short, then, we are sympathetic to the idea that novelty and obviousness in patent law should be relative, not absolute. ${ }^{67}$ Specifically, a patent should not be deemed invalid just because some ridiculously obscure piece of prior art can be found during litigation. If the prior art is that obscure, the patent holder should be treated like any other inventor, because, but for the patent holder, the invention would not have been available to society anyway. But the presumption of validity is not the instrument with which to address this problem. Prior art rules should ensure, and to some extent already do ensure, that too obscure a reference is treated as if it never existed. ${ }^{68}$ The presumption of validity, by contrast, weighs against all prior art references, even prior art that was known to experts in the field but for some reason failed to catch the attention of the patent examiner. Thus, the presumption is a poor solution to the problem of obscure art, and courts should instead continue to develop practical rules about how public a prior art reference must be before it will be deemed admissible as evidence against patent validity.

\footnotetext{
$67 \quad$ See Daralyn J. Durie \& Mark A. Lemley, A Realist Approach to the Obviousness of Inventions (vaporware 2007) (making this argument).

68. See, e.g., Atmel Corp. v. Info. Storage Devices, Inc., 198 F.3d 1374 (Fed. Cir. 1999) (requiring that, to be prior art, a reference must be reasonably accessible to the public). H.R. 2795 would have enshrined this standard in the statute.
} 


\section{Trained Patent Examiners Are Better at Determining Validity than Generalist Judges and Lay Juries.}

Patent litigation is, without doubt, a deeply flawed process. District court judges are poorly equipped to read patent documents and construe technical patent claims. Lay juries have no skill when it comes to evaluating competing testimony about the originality of a technical accomplishment. Even the specialized judges of the Federal Circuit are widely criticized for their inability to resolve intracircuit patent law splits. ${ }^{69}$ All this leaves us with little confidence that court decisions in the patent arena will necessarily map well to the public policy motivations that justify the existence of a patent system in the first place.

Our proposal, however, is not designed to shift decision-making power away from patent examiners and toward judges or juries. Quite the opposite. The second prong of our proposal explicitly advocates a new pay-more/getmore examination process that would be based in the PTO, and the third prong endorses PTO procedures such as inter partes reexamination and post-grant opposition. Our argument here is therefore not that courts are necessarily better than the PTO in all contexts. Rather, our argument is that the PTO's initial review is so constrained by budgetary and informational limitations that decisions made in that context should be reevaluated by some other decisionmaker - be it courts, the PTO acting later in time, or even a third entity like the International Trade Commission.

Nevertheless, our proposal will admittedly shift some decision-making authority to the courts, because at least some patent holders will skip all of the PTO's second-look measures and thus will end up defending their patents in litigation. We worry about whether the courts will be able to handle those cases reliably, and we support wholeheartedly experiments and conversations about ways to improve the quality of litigation outcomes. To the extent that the choice is between initial patent review at the PTO and later patent review in court, however, courts have the clear advantage. After all, patent litigation is adversarial, it takes place later in time, and it applies to a small enough fraction of patents that the parties can devote significant resources to hiring experts, searching for prior art, and in other ways rigorously analyzing the merits of the case.

\section{The PTO Will Have Incentives to Grant Bad Gold-Plated Patents}

So far, we have been discussing primarily objections likely to be raised by patent owners. Those who fear being accused of infringement might have a

69. See, e.g., William C. Rooklidge \& Matthew F. Weil, En Banc Review, Horror Pleni, and the Resolution of Patent Law Conflicts, 40 SANTA Clara L. ReV. 787 (2000).. To be fair to the Federal Circuit, we believe the conflict problem was much worse in the 1990s than it is today, in part because the court has taken several issues en banc to resolve conflicts. 
different worry: that the PTO will simply grant gold-plated patents as a matter of course, just as it grants the overwhelming majority of patents under the current system. ${ }^{70}$ This is likely to be a particular worry if the PTO becomes dependent on the higher fees associated with gold-plated applications, so that it has a bureaucratic incentive to encourage applicants to use the system, or if examiners of these gold-plated patents find it easier or more rewarding to grant than to deny patents, as some argue is the case today under the normal patent system. A "gold-plated" patent is only as good as the examination process that creates it, and, admittedly, if they are too easy to obtain, the point of the system will be lost.

We think these are serious design issues that need to be addressed, and they are a reason to prefer adversarial decisions where feasible, but the need for care in designing the system is not a reason to reject the system altogether. The resource problem can be solved by having a separate examiner unit evaluate gold-plated patents, as the PTO has recently done for reexaminations, and making that unit revenue-neutral. If the unit pays for itself, but is neither a drain on PTO resources nor a source of funding, there will be no incentive for the PTO to try to push applicants towards or away from the gold-plated option. A separate examining corps may also help insulate the new examiners from the pro-patent mindset that has arguably infected the rest of the examining corps. Promotion and pay rules should similarly ensure some degree of neutrality. For instance, examiners in the new unit should not be paid based on the number of patents reviewed or (worse) approved, nor should their tenure turn on "customer" satisfaction, given that patent applicants all clearly want just one thing.

\section{E. Presumptions Don't Matter Anyway}

Eliminating the clear and convincing evidence presumption of validity will not radically remake patent litigation. Accused infringers would still have to persuade a jury to second-guess what the PTO had done. And some will argue that factfinders do what they want, and that presumptions don't matter at all. But we think that goes too far. Admittedly, this is an area of uncertainty. We know far less than we should about how presumptions affect litigation decisions. The lack of empirical evidence on this point may be endemic: as Priest and Klein have suggested, changes in substantive legal rules also change the behavior of parties in deciding which cases to litigate, ${ }^{71}$ so it is far from a simple matter to predict how changes in a legal presumption would change actually rejects $15-20 \%$ of applications).

George L. Priest \& Benjamin Klein, The Selection of Disputes for Litigation, 13 J. Legal Stud. 1, 16 (1984). 
actual case outcomes.

While we can't prove that presumptions matter, we believe that they likely do, at least at the margins. When the Federal Circuit strengthened the presumption of validity in the early 1980s, the rate at which patents were held valid increased significantly. ${ }^{72}$ While there may be many causes for this increase, the stronger presumption of validity is one of the most plausible. And even if juries don't fully understand what the presumption means, courts do, and most validity determinations are made pretrial. ${ }^{73}$ We don't know exactly how often the presumption makes a difference to a case outcome, but we're reasonably confident that at least sometimes it does.

Finally, it's worth noting that even if we're wrong - if the presumption of validity doesn't matter much - that is not a reason not to adopt our proposal. It means, at most, that our approach won't do enough good, but for the same reason it also won't do much harm, since it won't have changed the strength of the patent right in litigation. We think trying to design the right incentives is worth the attempt, even if it turns out that the cynics are right and the merits don't matter.

\section{EFFECTS ON CURRENT STAKEHOLDERS}

Our proposal will have implications for a large number of stakeholders who are in one way or another involved with the patent system. In this Part, we consider which stakeholders might be helped by these reforms and which might be disadvantaged.

The primary beneficiaries of patent reform are not necessarily patent holders. Instead, the primary beneficiaries are the countless firms who, in the course of putting out some product or service, might inadvertently infringe a patent. These firms need the patent system to exercise due care to ensure that only genuine inventions are awarded patent protection, because these firms are the ones who will end up paying royalties, having to redesign their products, or in other ways having their businesses disrupted if some obvious idea is patented. For patent reform, this dynamic poses a problem. Reform efforts work best when the beneficiaries are a concentrated group that can be rallied to the cause. Here, the beneficiaries constitute an enormously diverse group, with members ranging from Internet start-ups to large manufacturing entities and financial institutions. Reforms of the sort we advocate here will as a result be difficult to accomplish, though the growing recognition of the patent troll

\footnotetext{
$72 \quad$ See Allison \& Lemley, Empirical Evidence, supra note __, at _ (noting increase in validity from $35 \%$ to $54 \%$ ).

See Jay P. Kesan \& Gwendolyn G. Ball, How Are Patent Cases Resolved? An Empirical Examination of the Adjudication and Settlement of Patent Disputes, 84 Wash. U.L. Rev. 237 (2006) (reporting that far more patent cases are resolved on summary judgment than at trial).
} 
problem by information technology companies is a start.

One important group that might be disadvantaged by these reforms is the group of firms that exploit today's rules by suing on patents that never should have been issued in the first place. A cottage industry has emerged to do exactly this, with certain firms widely accused of using the presumption of validity to turn dud patents into disruptive moneymakers. These "patent trolls" do not in any way contribute to innovation. They do not directly bring new ideas into public use, for instance by producing products, nor do they bring new ideas into public use through indirect means, for instance by introducing potential licensees to the patented technology. Instead, these firms wait for their victims to independently develop the obvious "inventions" their patents cover, and then sue or threaten to sue in order to extract their unearned reward. Patent reform will be difficult because these firms have substantial resources and they will use those resources to defend the status quo. But patent reform is at the same time essential because of the disruptions for which these firms are increasingly responsible.

At least two additional categories of patent holders might also oppose the reforms we suggest here: patent holders in the pharmaceutical industry and individual inventors. Patent holders in the pharmaceutical industry are cautious about any reform that might weaken patent strength, primarily because of the slippery slope concern that someday their patents might be targeted by wellmeaning lawmakers who mistakenly think that weaker patents would mean lower drug prices and better drug availability. Individual inventors are similarly cautious when it comes to patent reform. The deck is already stacked so heavily against individual inventors in terms of their ability to detect infringement and to litigate high-stakes cases to completion that any reduction in their ability to enforce their rights is understandably viewed with enormous skepticism. We have tried to make our proposal as palatable to these inventors as possible without undermining the goal of weeding out bad patents.

Other patent holders will admittedly be nervous to see the presumption of patent validity weakened, but they ought to support these reforms nonetheless. The reason is that the underbrush of undeserving patents undermines the value of well-earned patent rights. This plays out in a number of ways. For instance, many patent holders produce products or offer services consistent with their patent grants. These firms should favor patent reform for the same reasons that firms in general should: bad patents are a tax on legitimate business activity, including the legitimate use of patents that were fairly earned. Other patent holders, meanwhile, do not produce products or offer services directly, but instead license their patents to other firms that in turn do those things. These patent holders should support reform for two reasons. First, their businesses are built on licensing revenue, and there will be more licensing revenue for them if their licensees do not have to pay for dud patents. Second, these firms in particular rely heavily on the existence of a strong patent system; the more the patent system is abused, the more likely it is that Congress and the courts will 
weaken patent rights in response. The recent Supreme Court case of eBay Inc. v. MercExchange, L.L.C. is in this regard a clarion call. ${ }^{74}$ The Court in that case significantly restricted what had been the standard remedy for patent infringement, and did so largely because particular patent holders have in recent years very publicly abused the stronger rights that had previously been the norm. Fortunately, that opinion gave courts the flexibility needed to weaken patent rights for patent trolls without interfering with more legitimate patent use. But the broader lesson should be clear: legitimate patent holders need to drive their less honorable counterparts out of the tent, or the weakening of patent rights might become a dangerous trend.

\section{CONCLUSION}

Evaluating patent applications is a difficult task, and it is not a criticism of the PTO to point out that the current process results in the issuance of an uncomfortably large number of undeserving applications. Those errors can be corrected, but only if some second evaluative body is given an opportunity to revisit the initial decision to issue. The presumption of validity today makes that difficult. Thus, the patent system wastes the many advantages that a second decision-maker might have: the opportunity for adversarial review, sufficient resources to devote to a smaller number of important patents, and reliable outsider information about (for example) how well the product was received and whether other inventors achieved roughly the same breakthrough at roughly the same time. The result is a patent system that needlessly and significantly disrupts legitimate business activity.

The patent system can be fixed. By tailoring the presumption of patent validity to the realities of patent review, the patent system could ensure that there is deference to decisions that are likely reliable, but a chance to revisit decisions that are hampered by budgetary and informational constraints. Reasonable minds might disagree over the details of how best to implement that reform. For instance, there are colorable arguments for giving slightly more or less of a presumption in various situations, and colorable arguments for tweaking the timing of the various patent procedures we describe. Importantly, however, there is no colorable defense for the status quo. The initial patent review done by the PTO is an important step in the patent process, but it cannot bear the substantial weight it is given under current patent doctrine and practice.

74. 126 S. Ct. 1837 (2006). 